\title{
TRANSLATION AND APPARATUS
}

Translation is always choice, and translation of texts in legal theory faces double the ordinary difficulty of choosing. The translator faces the usual task of rendering German thoughts that all too often do not "think" in English, when differences in cultural tradition and linguistic habits propel thinking in different directions. But the translator of legal theory must also make available the words, ideas, and themes of a legal system and theory that map the world in ways that are not easily comprehensible to those steeped in the common law tradition. Unlike most specialized fields of knowledge, law and legal theory have languages and sets of principles and understandings that are not wholly universal. A theorem by Carl Friedrich Gauss on the algebra of groups, once translated, can be thoroughly grasped by any adequately trained mathematician. But the translation of an essay in Staatsrechtslehre by Triepel or Thoma, Kelsen or Schmitt, can be fully understood only if it makes the relevant portions of German law and legal theory transparent to readers in a different tradition.

In editing the translations in this volume, we have tried as far as possible to make the ideas and spirit of the works transparent to the educated reader of English. When direct and plain translations of the German words accomplish this purpose, we have used them, despite some awkwardness in the music. Often enough, however, direct and plain translation successfully communicates the stylistic power and passion of the original German. When direct and plain translation is impossible, either because English does not think the German thought or because an institution of German law or legal theory does not exist in the same way in the common law tradition, then we have been forced to craft a suitably transparent English substitute. In so doing, we have avoided using lengthy notes describing German 
legal institutions. Rather, we have insisted on finding formulations that transparently convey the institutions in the text itself.

Besides transparency, our guiding principle has been consistency within texts, and from text to text. The Rechtsstaat, whether used by Heller or Schmitt, remains the "state based on the rule of law," even though Heller and Schmitt bring to it vastly different attitudes and meanings. It is precisely consistency that allows one to map variations in attitude that Weimar theorists had toward their common legal and theoretical heritage. At the same time, consistency must sometimes yield to a lack of congruence between German and English terms. For example, Herrschaft is almost always "domination," but Majoritätsherrschaft must be "majority rule," as "domination by a majority" would be too odd a departure from the standard English. We have usually chosen, nonetheless, to tolerate oddness in order to achieve the virtue of consistency.

In the same spirit of transparency and consistency we have updated the citations in the works of the Weimar theorists to conform to modern practice. We have also included citations to modern editions, unavailable during Weimar, so that readers may have broader access to the rich literature upon which Weimar theorists drew. To that end, the writers of the introductions have compiled the main works of the theorists and the significant scholarly commentary.

Unless otherwise indicated, the translator is Belinda Cooper. The general editors have reviewed each translation for consistency, accuracy, and style. The introductory essays by Peter C. Caldwell, Stephen Cloyd, and David Dyzenhaus, and parts of the general introduction, were originally written in English. 